\begin{tabular}{l|l} 
Jurnal Eksplorasi Akuntansi & $\begin{array}{l}\text { ISSN : 2656-3649 (Online) } \\
\text { hol. 2, No 2, Seri A, Mei 2020, Hal 2620- } 2637\end{array}$
\end{tabular}

\title{
PENGARUH GENDER, DUKUNGAN ATASAN, DAN PROTEKSI TERHADAP KEPUTUSAN PENGUNGKAPAN KECURANGAN PADA PEMERINTAH DAERAH DI SUMATERA BARAT
}

\author{
Lara Fatma Sarni ${ }^{1}$, Herlina Helmy ${ }^{2}$, Vita Fitria Sari ${ }^{3}$ \\ ${ }^{1}$ Alumni Jurusan Akuntansi Fakultas Ekonomi Univesitas Negeri Padang \\ ${ }^{2}$ Jurusan Akuntansi Fakultas Ekonomi Univesitas Negeri Padang \\ *Korespondensi: larafatmasarni@gmail.com
}

\begin{abstract}
This study aims to determine empirically the influence of gender, superiors support, and protection of fraud disclosure decision local government in West Sumatra. This research is quantitative research. The population in this study were students of Master of Management at Universitas Negeri Padang and Master of Accounting at Universitas Andalas. The sample in this research was taken by using purposive sampling, namely 81 samples. The data collection method used is a survey method in the form of a questionnaire given personally. Data processing is performed using SPSS. The results of this research indicate that Gender does not significantly influence the decision to disclose fraud to local governments in West Sumatra. The results of hypothesis testing with two way ANOVA test (two way ANOVA), showed that the supervisor support variable gets a significant value of 0,000, it can be concluded that superiors support has a significant effect on fraud disclosure decisions in local governments in West Sumatra and the protection variable also gets significant value of 0,000, so it can be concluded that protection has a significant effect on fraud disclosure decisions in local governments in West Sumatra.
\end{abstract}

Keywords: Deception Disclosure Decisions ,Gender, Protection, Superior Support

How to cite (APA $6^{\text {th }}$ style):

Sani, L F., Helmy, Herlina., Sari, V F. (2020). Pengaruh Gender, Dukungan Atasan, dan Proteksi terhadap Keputusan Pengungkapan Kecurangan pada Pemerintah Daerah di Sumatera Barat. Jurnal Eksplorasi Akuntansi. 2(2), Seri A, 2620-2637.

\section{PENDAHULUAN}

Association of certified Fraud Examiners (ACFE, 2012) mendefinisikan kecurangan sebagai penyalahgunaan yang disengaja untuk keperluan pribadi. ACFE (2012) mengkategorikan kecurangan dalam tiga kelompok, yaitu: 1) kecurangan laporan keuangan (financial statement fraud), merupakan kecurangan yang dilakukan oleh menajemen dalam bentuk salah saji material laporan keuangan. 2) penyalahgunaan aset (asset misappropriation) dan kecurangan pengeluaran-pengeluaran biaya (fraudulen disbursment), dan 3) korupsi (corruption), dibagi 
dalam pertentangan kepentingan (conflict of interest), suap (bribery), pemberian ilegal (illegal gratuity), dan pemerasan (economic extortion).

Tindakan kecurangan dapat terjadi di organisasi pemerintahan maupun di organisasi swasta. Kecurangan yang sering terjadi di organisasi pemerintah yaitu korupsi. Korupsi yang terdapat pada organisasi pemerintahan di indonesia mengacu pada UU TPK No. 31 tahun 1999. Pada pasal 2 ayat (1) menyatakan bahwa korupsi adalah orang yang secara melawan hukum melakukan perbuatan memperkaya diri sendiri atau orang lain yang dapat merugikan keuangan dan perekonomian negara, ayat (2) dilakukan dalam keadaan tertentu.

Praktik-praktik kasus korupsi hampir terjadi di setiap daerah di Indonesia, terbukti dari data KPK tahun 2004 sampai bulan Mei 2016 berjumlah 56 orang yang melibatkan kepala daerah (acch.kpk.go.id). Indonesian Corruption Watch (ICW) menemukan pihak yang paling banyak terjerat kasus korupsi selama tahun 2015 adalah PNS di lingkungan pemerintah daerah (Beritasatu.com. minggu, 7 Februari 2016). Misalnya kasus korupsi terkait dengan proses perencanaan, penganggaran, dan pelaksanaan proyek pengadaan barang dan jasa di Dinas Pendidikan dan dinas-dinas lainnya di lingkungan Pemerintah Kabupeten Banyuasin yang dilakukan oleh Rustami (PNS - Kasubag Rumah Tangga Pemkab Banyuasin tahun 2016). Kasus serupa terjadi pada Gubernur Banten yaitu Ratu Atut Chosiyah yang melakukan korupsi pengadaan sarana dan prasarana alat kesehatan dan pengadaan lainnya di lingkungan Pemerintah Provinsi Banten pada tahun 2011 sampai 2013.

Pengungkapan kecurangan atau disebut juga dengan whistleblowing adalah tindakan yang dilakukan oleh anggota atau organisasi atas praktik yang tidak bermoral dan tidak sah kepada orang atau lembaga yang mungkin dapat mempengaruhi tindakan (Miceli, 2004). Sedangkan menurut Komite Nasional Governance (2008) whistleblowing merupakan pengungkapan perbuatan yang melawan hukum,perbuatan yang tidak bermoral atau perbuatan lain yang dapat merugikan organisasi atau pemangku kepentingan. Seseorang yang memberitahukan kepada publik atau pejabat yang berkuasa terhadap dugaan ketidakjujuran, kegiatan ilegal atau kesalahan yang terjadi di pemerintahan, organisasi publik, atau swasta disebut whistleblower (Susmanchi, 2012).

Menurut Rotschild dan Miethe (1999) whistleblowing dapat dipandang dari dua sisi. Yang pertama, whistleblowing dianggap sebagai bentuk pengkhianatan karena telah mengungkapkan masalah yang ada di dalam organisasi, sehingga pegawai yang telah melakukan pengungkapan tersebut dianggap telah melanggar norma loyalitas organisasi. Yang kedua, whistleblowing dianggap sesuatu yang positif karena telah melindungi nilai-nilai kebenaran yang lebih penting dari loyalitas kepada organisasi. Pandangan yang berbeda tersebut membuat seseorang yang akan melakukan tindakan whistleblowing menghadapi dilema etis dalam memutuskan untuk tetap mengungkapkan atau membiarkan kecurangan tersebut tetap terjadi.

Berbagai kasus yang terjadi di Indonesia terkait whistleblowing telah mendorong Komite Nasional Kebijakan Governance (KNKG) untuk menerbitkan Pedoman Sistem Pelaporan Pelanggaran atau whistleblowing system (WBS) pada 10 November 2008. Pedoman Sisem Pelaporan Pelanggaran dapat digunakan oleh perusahaan untuk mengambangkan sistem manual pelaporan pelanggaran pada masing-masing perusahaan. Tujuannya adalah sebagai panduan bagi organisasi yang ingin membangun, menerapkan, dan mengelola suatu Sistem Pelaporan Pelanggaran (SPP). Dengan adanya sistem pelaporan pelanggaran akan mendorong karyawan untuk lebih berani bertindak dalam mencegah terjadinya pelanggaran dengan melaporkan kepada pihak yang lebih berwewenang. 
Sistem whistleblowing yang efektif, transparan, dan bertanggungjawab akan mendorong karyawan untuk melaporkan dugaan kecurangan yang diketahuinya. Mekanisme pelaporan dan perlindungan terhadap pelapor atau whistleblower belum sepenuhnya diatur dengan jelas dan tegas dalam perundang-undangan. Akan tetapi, beberapa kementrian/lembaga misalnya: Kementrian keuangan, Komisi Pemberantasan Korupsi (KPK), Lembaga Kebijakan Pengadaan Barang/Jasa Pemerintah (LKPP), Badan Perencanaan dan Pembangunan Nasional (Bappenas), Komisi Yudisial (KY), Komisi Kejaksaan, Ombudsman, Komisi Nasional Hak Asasi Manusia (Komnas HAM), Pusat Pelaporan dan Analisis Transaksi Keuangan (PPATK) telah memiliki pedoman sisem pelaporan pelanggaran (whistleblowing system).

Penelitian whistleblowing sebagian besar difokuskan pada dua faktor yang dapat mempengaruhi pelaporan: (a) faktor individu, (b) faktor organisasi, seperti struktur organisasi, kebijakan pengungkapan internal, kode etik, sistem kompensasi, serta budaya dan iklim organisasi. Pemahaman tentang proses menjadi rumit kerena adanya kompleksitas variabel dan interaksi di antara variabel-variabel. Oleh karena itu, penelitian selanjutnya memerlukan identifikasi interaksi dari faktor-faktor yang mempengaruhi whistleblowing agar whistleblowing efektif. Pada dasarnya penelitian saat ini menekankan pada faktor individu yang dapat mempengaruhi keputusan whistleblowing dan faktor organisasi pada proses whistleblowing. Akan tetapi, penelitian saat ini melalaikan aspek penting dalam manajemen whistleblowing. Penelitian hanya terfokus pada whistleblower dan bukan pada proses penanganan masalahnya. Hal ini mengakibatkan perlunya penelitian yang berkonsentrasi pada whistleblowing yang efektif dan meneliti faktor individu yang melakukan whistleblowing.

Whistleblowing dapat dipengaruhi oleh faktor gender. Pengungkapan kecurangan dapat dilakukan oleh siapa saja, baik itu laki-laki maupun perempuan. Tetapi dalam hal etika, keyakinan, nilai-nilai, dan perilaku antara laki-laki dan perempuan sangatlah berbeda. Menurut Vermeir (2008) bahwa perempuan lebih etis dalam penilaian dan bersikap, karena perempuan lebih memikirkan konsekuensi yang akan diterima ketika menjadi whistleblower, seperti dikucilkan atau diberi sanksi lainnya. Sedangkan laki-laki dianggap lebih mampu dalam mengatasi masalah sendiri dan mampu menerima konsekuensi yang akan diterimanya ketika melakukan whistleblowing.

Faktor lain yang mempengaruhi whistleblowing adalah dukungan atasan. Seifer et al. (2010) menerapkan teori keadilan organisasi untuk desain kebijakan dan prosedur whistleblowing. Keadilan interaksional berfokus pada kualitas perlakuan yang diterima karyawan dari atasan ketika prosedur yang ada dalam organisasi dijalankan. Persepsi keadilan interaksional terbentuk dari pertukaran interpersonal antara manajer dan bawahan. Interaksi informal antara bawahan dan atasan akan dapat merusak proses formal, sebagai contoh, ancaman pembalasan dari atasan akan menjadi pertimbangan karyawan dalam melakukan whistleblowing, karena akan mengancam keberadaan whistleblower. Jika atasan tidak melakukan ancaman pembalasan terhadap whistleblower maka interaksi yang terjadi akan adil. Dukungan yang diberikan oleh atasan berperan penting dalam keputusan whisteblowing.

Keil et al. (2010) menyatakan bahwa manfaat dapat dirasakan ketika karyawan melakukan pengungkapan kecurangan meningkat ketika dukungan yang diberikan atasan meningkat. Karyawan akan melakukan pengungkapan jika mendapat dukungan dari atasannya (supervisor support). (Kottke dan Sharafinski, 1988) mengungkapkan bahwa karyawan akan membentuk persepsi mengenai sejauh mana atasan menghargai kontribusi dan peduli tentang kesejahteraan mereka. 
Faktor lainnya yang mempengaruhi whistleblowing adalah proteksi. Proteksi merupakan perlindungan yang diberikan kepada karyawan dari bentuk-bentuk pembalasan terhadap whistleblower dalam kebijakan hotline akan mengurangi rasa ketakutan karyawan, sehingga akan memotivasi karyawan dalam melakukan pengungkapan kecurangan melalui hotline. Karyawan akan lebih berani melaporkan kesalahan yang terjadi jika suatu organisasi sudah menetapkan saluran internal secara formal dan memberikan proteksi. Menurut Rostchild dan Miethe (1999) organisasi tidak melakukan pembalasan terhadap whistleblower ketika kesalahan yang dilaporkan tidak memberikan dampak yang buruk terhadap organisasi.

Dalam membantu meringankan rasa takut pembalasan dan mendorong pengungkapan, ACFE (2012) merekomendasikan bahwa organisasi harus memberikan perlindungan antipembalasan kepada karyawan (misalnya kehilangan pekerjaan atau promosi, bentuk pembalasan pembalasan keuangan, dan perlindungan dari pelecehan), selain jaminan kerahasiaan dan anominitas dalam kebijakan hotline whistleblower (Mermer-Magmus dan Vismesvaran, 2005). Perlindungan dari pembalasan sangatlah penting bagi whistleblower atas resiko yang akan dihadapinya. Karena tingginya tingkat kecurangan yang terjadi di sektor pemerintahan membuat whistleblowing menjadi suatu keharusan bagi setiap pegawai, yang didukung oleh penyediaan sistem whistleblowing yang efektif dapat memudahkan pegawai dalam melaporkan kecurangan. Dengan adanya whistleblowing diyakini dapat mendeteksi lebih awal kasus kecurangan yang terjadi, agar kecurangan tidak berlanjut dan menimbulkan dampak kerugian yang lebih besar.

Perbedaan penelitian ini dengan penelitian sebelumnya yaitu penelitian Priyastiwi (2017) adalah yang pertama, objek penelitian ini adalah mahasiswa magister manajemen Universitas Negeri Padang dan mahasiswa akuntansi S2 Universitas Andalas, sedangkan pada penelitian Priyastiwi objek penelitiannya adalah mahasiswa magister akuntansi fakultas ekonomi dan bisnis UGM. Perbedaan lainnya pada penelitian ini dengan penelitian sebelumnya adalah penelitian ini menggunakan variabel independen gender, dukungan atasan dan proteksi sedangkan penelitian Priyastiwi (2017) menggunakan variabel dukungan atasan dan proteksi.

Tujuan dari penelitian ini adalah untuk mengetahui pengaruh gender, dukungan atasan dan proteksi terhadap keputusan pengungkapan kecurangan pada pemerintah daerah di Sumatera Barat. Penelitian ini diharapkan dapat menambah wawasan pengetahuan mengenai faktor-faktor yang mempengaruhi keputusan pengungkapan kecurangan pada pemerintah daerah di Sumatera Barat .

\section{REVIU LITERATUR DAN PENGEMBANGAN HPOTESIS Teori Pertukaran Sosial}

Teori pertukaran sosial atau social excange theory menjelaskan hubungan antara pegawai dengan organisasinya merupakan suatu pertukaran (Eisenberger et al., 1986). Menurut Eisenberger et al. (1986) bahwa pegawai menganggap bekerja merupakan bentuk pertukaran dengan kebutuhankebutuhannya, sehingga mereka melakukan penilaian pada organisasi yang mempunyai perhatian untuk usaha yang telah diberikannya dengan menerima imbalan. Pegawai juga akan menilai apakah kebutuhan akan pengakuan dan penghargaan juga terpenuhi (Aselage dan Eisenberger, 2003).

Eisenberger et al. (1986) menjelaskan bahwa dukungan organisasi dibentuk dari perlakuan-perlakuan organisasi yang diperoleh karyawan, seperti kenaikan jabatan, kepercayaan, pembayaran honorarium, dan partisipasi dalam membuat kebijakan organisasi. Penghargaan yang diberikan atas kesadaran organisasi, akan mempunyai pengaruh yang lebih besar terhadap 
dukungan organisasi dibandingkan dengan adanya tekanan dari luar, seperti tekanan serikat kerja (Rhoades dan Eisenberger, 2002).

Eisenberger et al. (1986) menyatakan bahwa dalam teori pertukaran sosial, orang yang menerima keuntungan tertentu akan mempunyai kewajiban untuk membalas dari apa yang telah diterimanya. Setiap tindakan yang dilakukan oleh karyawan merupakan suatu balasan dari tindakan yang dilakukan organisasi. Bagi karyawan, dukungan dari organisasi mencerminkan bagaimana pimpinan mempunyai komitmen untuk kepentingan mereka.

\section{Teori Reaktansi Psikologis}

Brehm, (1966); Brehm dan Brehm, (1981) mengemukakan bahwa teori reaktansi psikologis adalah upaya untuk membujuk individu agar bertindak dengan cara tertentu sering kontraproduktif, karena akan mengancam kebebasan individu. Menurut perspektif ini, individu yang di atur untuk bertindak dengan cara tertentu akan merasa perilaku kebebasan mereka akan terkurangi.

Whistleblower bisa juga disebut dengan pelaku kesalahan dalam organisasi. Sesuai dengan teori tekanan sosial (social pressure theory), tekanan sosial akan mempengaruhi tindakan seseorang untuk melakukan sesuatu namun bukan keinginan pribadi. Tindakan menyimpang yang dilakukan anggota organisasi sering terjadi karena tekanan sosial. Menurut Davis et al. (2006) yang menunjukan bahwa akuntan manajemen lebih mungkin untuk membuat slack anggaran ketika dihadapkan dengan tekanan ketaatan dari atasan langsung. Hasil ini menjelaskan temuan sebelumnya dalam literatur psikologi dan auditing bahwa tekanan sosial menginduksi kesesuaian individu untuk menghindari konsekuensi negatif yang muncul karena penyimpangan dari kelompoknya atau tidak setia kepada atasan yang otoritasnya yang lebih tinggi (Lord dan DeZoort, 1997).

Di dalam organisasi pemerintah, seseorang yang melakukan tindakan ilegal dan tidak bermoral, bukan karena motivasi diri sendiri, tetapi karena adanya tekanan sosial dari pimpinan organisasi. Menurut teori reaktansi psikologis, tekanan akan bisa menimbulkan reaktansi psikologis yang terjadi ketika sebuah kebebasan diancam dengan eliminasi (Brehm dan Brehm, 1981). Reaktansi akan memperimbangkan keadaan yang tidak menyenangkan, terdiri dari komponen emosi (misalnya perasaan marah), dan komponen kognitif (misalnya, sikap menolak terhadap otoritas). Menurut (Brehm, 1966) Reaktansi juga memerlukan perilaku kecendrungan untuk menolak perilaku terlarang.

\section{Keputusan Pengungkapan Kecurangan (Whistleblowing)}

Hoffman dan Robert (2008) mendefenisikan whistleblowing sebagai suatu pengungkapan yang dilakukan oleh seorang karyawan terkait dengan informasi yang diyakininya mengandung pelanggaran hukum, peraturan, pedoman praktis atau pernyataan profesional, korupsi, penyalahgunaan wewenang, atau yang membahayakan publik dan keselamatan tempat kerja. Bouvile (2007) juga menyatakan whistleblowing adalah suatu tindakan yang dilakukan oleh seorang pegawai (atau mantan pegawai) untuk mengungkapkan sesuatu yang ia percaya sebagai perilaku ilegal atau tidak etis kepada manajemen yang lebih tinggi/manajemen puncak (internal whistleblowing) atau kepada pihak yang lebih berwenang diluar organisasi maupun publik (eksternal whistleblowing). Selain itu, Komite Nasional Kebijakan Governance (KNKG) Indonesia juga menambahkan bahwa whistleblowing dilakukan dengan dasar itikad baik dan bukan merupakan keluhan pribadi terhadap kebijakan suatu organisasi. 
Whistleblowing akan muncul ketika terjadi konflik antara loyalitas karyawan dan perlindungan kepentingan publik. Elias (2008) menambahkan bahwa whistleblowing dapat terjadi dari dalam (internal) maupun dari luar (eksternal). Internal whistleblowing terjadi ketika seorang karyawan mengetahui sebuah kecurangan yang dilakukan oleh karyawan lainnya kemudian melaporkannya kepada pihak yang berwewenang atau kepada atasannya. Sedangkan eksternal whistleblowing terjadi ketika seorang karyawan mengetahui sebuah kecurangan yang dilakukan perusahaan lalu memberitahukannya kepada masyarakat karena kecurangan tersebut akan merugikan banyak pihak.

Hoffman dan Robert (2008) menetapkan ada tiga kriteria atas whistleblowing yang adil. Pertama, organisasi yang dapat menyebabkan bahaya terhadap para karyawan atau kepada kepentingan publik. Kedua, kesalahan yang terjadi harus dilaporkan pertama kali kepada pihak internal yang berwewenang atau memiliki kekuasaan yang lebih tinggi. Dan yang ketiga, apabila penyimpangan yang terjadi telah dilaporkan kepada pihak internal namun tidak mendapatkan hasil dan bahkan penyimpangan tersebut terus berjalan, maka tindakan lain yang harus dilakukan adalah melaporkannya kepada pihak eksternal.

Whistleblowing dapat dipandang sebagai bagian dari strategi untuk menjaga dan meningkatkan kualitas (Lewis, 2005). Sebagai seorang whistleblower seharusnya memiliki kinerja yang baik, beredukasi tinggi, berkedudukan sebagai pengawas, dan moral reasining yang lebih tinggi dibandingkan seorang pengawas fraud yang tidak aktif (Elias, 2008). Namun pengungkapan kecurangan yang sering terjadi pada umumnya menimbulkan konsekuensi yang tidak diinginkan oleh orang yang melakukan pengungkapan tersebut, seperti kehilangan pekerjaan, ancaman balas dendam, dan isolasi dalam bekerja.

Malik (2010) menggunakan dua aspek dari whistleblowing yaitu tentang pandangan terkait dengan persepsi whistleblowing dan whistleblowing intention. Persepsi whistleblowing dapat diukur dengan tingkat keseriusan tindakan yang dinilai dengan mempertimbangkan besarnya pelanggaran yang dilakukan pada masing-masing kasus. Malik (2010) menyatakan tingkat tanggung jawab untuk melaporkan pelanggaran dinilai dengan mempertimbangkan apakah pengungkapan tindakan yang diragukan tersebut merupakan suatu tugas karyawan sebagai bagian dari perusahaan atau hanya kewajiban pribadi. Sedangkan whistleblowing intention merupakan keinginan untuk melakukan whistleblowing yang merupakan salah satu bentuk dari keseriusan dalam situasi, tanggung jawab untuk melaporkan pelanggaran dan dampak negatif yang akan diterima sebagai akibat dari pengungkapan tersebut (Malik, 2010).

Hanif (2017) mengemukakan bahwa secara umum whistleblowing memiliki 4 tahapan, yaitu: pertama, seorang whistleblower harus mempertimbangkan apakah kejadian yang disaksikan merupakan suatu pelanggaran yang bertentangan dengan nilai-nilai dalam organisasi dan nilai-nilai yang dimiliki whistleblower itu sendiri. Kedua, whistleblower harus mempertimbangkan beberapa alternatif dalam mengambil keputusan. Whistleblower harus mengetahui pihak berwenang yang harus mendapat laporan. Dan juga harus mempertimbngkan dampak dari pelanggaran tersebut. Apakah pelanggaran tersebut dapat dihentikan atau tidak tanpa adanya pelaporan. Ketiga, organisasi harus segera bertindak setelah adanya laporan tentang whistleblowing. Keempat, organisasi harus dapat memutuskan tindakan terhadap whistleblower.

\section{Gender}

Gender merupakan salah satu faktor yang dapat mempengaruhi seseorang untuk melakukan keputusan pengungkapan kecurangan. Secara umum, pengertian gender adalah perbedaan yang tampak antara laki-laki dan perempuan apabila dilihat dari nilai dan tingkah laku. Slamet (2001) 
menyatakan bahwa gender atau jenis kelamin merupakan sebuah variabel yang mengekspresikan ketegori biologis, yang merupakan sifat manusia yang terkait oleh budaya dan seringkali dipertimbangkan menjadi sebuah penentu hubungan kausal di tempat kerja kerena adanya disparitas kekuatan yang membedakan manusia, sehingga mempunyai peran yang penting dalam proses sosialisasi.

Menurut Vermeir (2008) perempuan lebih etis dalam bersikap dan melakukan penilaian dibandingkan laki-laki. Perempuan lebih memikirkan konsekuensi yang akan diterima ketika menjadi whistleblower, seperti dikucilkan atau diberi sanksi lainnya. Sedangkan laki-laki dianggap lebih mampu dalam mengatasi masalah sendiri dan konsekuensi yang akan diterimanya ketika melakukan whistleblowing. Coate dan Frey (2000) menyatakan bahwa terdapat dua pendekatan yang biasa digunakan untuk memberikan pendapat tentang pengaruh gender terhadap perilaku etis maupun persepsi individu terhadap perilaku yang tidak etis. Pertama, pendekatan struktural yaitu perbedaan antara laki-laki dan perempuan disebabkan oleh sosialisasi awal pada pekerjaan dan kebutuhan-kebutuhan peran lainnya. Kedua, pendekatan sosialisasi yaitu laki-laki dan perempuan membawa perangkat nilai yang berbeda ke dalam suatu lingkungan kerja maupun lingkungan belajar. Pada pendekatan ini perbedaan nilai dan sifat berdasarkan gender ini akan mempengaruhi laki-laki dan perempuan dalam mengambil keputusan dan praktik. Laki-laki lebih cenderung bersaing dalam mencapai kesuksesan dan lebih sering melanggar peraturan yang ada dan memandang pencapaian prestasi sebagai suatu persaingan. Laki-laki lebih mementingkan kesuksesan akhir (relative performance), sedangkan perempuan lebih mementingkan self-performance. Perempuan lebih fukus pada pelaksanaan tugas dengan baik dan hubungan kerja yang harmonis, sehingga perempuan lebih cenderung patuh terhadap peraturan yang ada dan lebih memilih kritis terhadap orang-orang yang melanggar peraturan tersebut.

\section{Dukungan Atasan}

Dukungan atasan adalah ketika atasan memperlakukan bawahan dengan secara hormat, menghargai, sopan, serta mempercayai informasi dan penjelasan yang benar. Oleh karena itu, dukungan atasan bentuk perilaku atas bawahan dengan dukungan, perhatian, kepercayaan dan penghormatan untuk whistleblower potensial (Eisenberger et al., 2002). Interaksi dengan manajemen digambarkan dalam 2 hal: yaitu, dukungan atasan yang tinggi terkait dengan kepercayaan, perhatian, dukungan dan penghormatan yang tinggi. Sedangkan dukungan atasan yang rendah adalah sikap mengancam pelapor, tidak percaya, dan tidak menghiraukan informasi yang diberikan oleh pelapor.

Kottke dan Sharafinski (1988) mengemukakan bahwa karyawan mengembangkan pandangan umum bahwa atasan berkontribusi terhadap kesejahteraan mereka. Dikarenakan atasan bertindak sebagai agen organisasi, maka atasan memiliki tanggung jawab untuk memimpin dan mengevaluasi kinerja bawahannya. Pandangan karyawan terhadap atasannya yaitu atasan bertindak menguntungkan karyawan sebagai indikasi dari dukungan organisasi (Eisenberger et al., 2002). Selain itu, karyawan memahami bahwa evaluasi yang diberikan atasan terhadapnya sering disampaikan kepada top manajemen, yang pada akhirnya berkontribusi terhadap hubungan dukungan atasan dengan kinerja karyawan. Dukungan dari atasan telah dinilai terkait pengukuran kinerja yang melibatkan pertukaran pemimpin-anggota dan pertimbangan atasan.

Sebagian besar teori menjelaskan bahwa hubungan antara organisasi dengan kepercayaan karyawan yaitu ketika karyawan melihat atasan sebagai agen organisasi. Misalnya, teori kontrak 
psikologis (Rousseau, 1989) berpendapat bahwa karyawan menganggap janji-janji yang telah diberikan atasan merupakan janji dari organisasi. Oleh karena itu, karyawan berasumsi hubungan pertukaran mereka dengan atasan sebagai pertukaran dengan organisasi karena mereka melihat atasan sebagai wakil dari organisasi. Eisenberger et al., (2010) menyatakan bahwa karyawan membentuk persepsi tentang kesamaan antara atasan dengan organisasi sebagai perwujudan dari organisasi pengawas (SOE/Supervisor Organization Embodiment). Jika semakin besar SOE, maka semakin besar karyawan merasakan bahwa perlakuan yang diberikan atasan adalah sebagai perlakuan dari organisasi pula. Dan juga, Near dan Miceli (1996) menemukan bahwa kurangnya dukungan dari atasan dan top manajemen akan menurunkan whistleblowing. Pemimpin yang memiliki etika etis akan mendukung, mendorong, dan memotivasi karyawan untuk mengungkap kesalahan yang terjadi.

\section{Proteksi}

Proteksi ditunjukan dengan perlindungan yang diberikan kepada karyawan dari pembalasan atas pengungkapan yang dilakukan oleh karyawan sesuai dengan Undang-Undang Perlindungan Saksi dan Korban No 13 Tahun 2006. Menurut Saksi dan Korban (2006), whistleblower adalah orang yang memberikan informasi kepada pihak yang berwenang atau pihak penegak hukum mengenai terjadinya suatu tindak pidana. Proteksi meliputi perlindungan dari ancaman, keluarga dan hartanya, jaminan keamanan diri, dan tidak ada tuntutan hukum terhadap pelapor. Proteksi yang tinggi ditunjukkan ketika pelapor mendapatkan seluruh jaminan yang aman. Sedangkan proteksi yang rendah adalah ketika pelapor tidak mendapatkan proteksi tersebut, tetapi hanya jaminan yang berhubungan dengan masalah di pengadilan.

Salah satu cara yang dilakukan untuk mengurangi rasa takut terhadap pembalasan dan meningkatkan kesediaan karyawan untuk melaporkan, organisasi telah menyertakan jenis proteksi dalam kebijakan hotline whistleblower (Wainberg dan Perreault, 2006). Yang artinya, selain menyediakan saluran pelaporan, rahasia dan anonim, juga memasukkan bentuk-bentuk proteksi khusus dari pembalasan (seperti kehilangan pekerjaan, kehilangan promosi, pelecehan, konsekuensi keuangan, profesionalisme yang jatuh, dan hukuman). ACFE (2012) merekomendasikan proteksi terhadap pembalasan untukditawarkan kepada karyawan.

\section{Penelitian Terdahulu}

Penelitian mengenai pengaruh gender, dukungan atasan dan proteksi terhadap kepuusan pengungkapan kecurangan pada pemerintah daerah Sumatera Barat adalah Priyastiwi (2017).

a. Fraud dan whistleblowing: pengungkapan kecurangan akuntansi oleh auditor pemerintah (Rheny Afriana Hanif (2012))

b. Toward a conceptual model of whistle-blowing intentions among external auditors (Philmore Alleyne (2012))

c. The Influence of Individual and Situasional Factors on Lower-level Civil Servant's Whisleblowing Intention in Indonesia (Rijadh Djatu Winardi (2013))

d. Faktor-faktor yang Mempengaruhi Minat PNS untuk melakukan tindakan Whistleblowing (Rizki Bagustianto (2014))

e. Profesionalisme, komitmen organisasi, intensitas moral dan tindakan akuntan melakukan whistleblowing (Luh Putu Setiawati (2016). 


\section{Pengembangan Hipotesis}

Berdasarkan uraian diatas, maka pengembangan hipotesis dan hipotesis untuk penelitian ini adalah sebagai berikut.

\section{Gender}

Berdasarkan gender, laki-laki dan perempuan membawa nilai-nilai dan pemikiran yang berbeda yang dapat mempengaruhi keputusan, meskipun mereka bearada dalam suatu lingkungan kerja yang sama. Menurut Vermeir (2008) bahwa perempuan lebih etis dalam penilaian dan bersikap, karena perempuan lebih memikirkan konsekuensi yang akan diterima ketika menjadi whistleblower, seperti dikucilkan atau diberi sanksi lainnya. Sedangkan laki-laki dianggap lebih mampu dalam mengatasi masalah sendiri dan mampu menerima konsekuensi yang akan diterimanya ketika melakukan whistleblowing.

$\mathbf{H}_{\mathbf{1}}$ : Laki-laki lebih cenderung untuk melakukan tindakan keputusan pengungkapan kecurangan dari pada perempuan.

\section{Dukungan Atasan}

Karyawan memandang bahwa atasan berkontribusi terhadap kesejahteraan mereka, karena atasan bertindak sebagai agen organisasi yang memiliki tanggung jawab untuk memimpin dan mengevaluasi kinerja bawahannya. Pandangan karyawan terhadap atasannya yaitu atasan bertindak menguntungkan karyawan sebagai indikasi dari dukungan organisasi (Eisenberger et al., 2002). Selain itu, karyawan memahami bahwa evaluasi yang diberikan atasan terhadapnya sering disampaikan kepada top manajemen, yang pada akhirnya berkontribusi terhadap hubungan dukungan atasan dengan kinerja karyawan. Dukungan dari atasan telah dinilai terkait pengukuran kinerja yang melibatkan pertukaran pemimpin-anggota dan pertimbangan atasan.

Sebagian besar teori menjelaskan bahwa hubungan antara organisasi dengan kepercayaan karyawan yaitu ketika karyawan melihat atasan sebagai agen organisasi. Oleh karena itu, karyawan berasumsi hubungan pertukaran mereka dengan atasan sebagai pertukaran dengan organisasi karena mereka melihat atasan sebagai wakil dari organisasi. Eisenberger et al., (2010) menyatakan bahwa karyawan membentuk persepsi tentang kesamaan antara atasan dengan organisasi sebagai perwujudan dari organisasi pengawas (SOE/ Supervisor Organization Embodiment). Jika semakin besar SOE, maka semakin besar karyawan merasakan bahwa perlakuan yang diberikan atasan adalah sebagai perlakuan dari organisasi pula. Dan juga, Near dan Miceli (1996) menemukan bahwa kurangnya dukungan dari atasan dan top manajemen akan menurunkan whistleblowing. Pemimpin yang memiliki etika etis akan mendukung, dan memotivasi karyawan untuk mengungkap kesalahan yang terjadi.

$\mathbf{H}_{2}$ : Dukungan atasan berpengaruh positif terhadap keputusan pengungkapan kecurangan.

\section{Proteksi}

Association of Certified Fraud Examiners (ACFE, 2012) menemukan bahwa whitleblowing merupakan metode yang biasa dilakukan untuk mendeteksi kecurangan. Seorang auditor mempunyai peran penting dalam mendeteksi kecurangan pelaporan keuangan melalui hotline whistleblower yang memadai. Akan tetapi, biasanya auditor sering menerima konsekuensi rusaknya reputasi perusahaan klien yang diauditnya.

Sebagian besar penelitian yang dilakukan terhadap dampak dari ketentuan anomitas whistleblower dan pilihan outlet pelaporan eksternal pada keputusan untuk melakukan pengungkapan kesalahan. Misalnya, Curtis dan Taylor (2009) telah melakukan survey terhadap 
auditor dan menemukan bahwa partisipan kurang bersedia untuk melakukan pelaporan kesalahan yang tidak etis tersebut ketika identitas mereka diungkapkan. Sedangkan Robertson et al., (2011) menemukan bahwa auditor lebih memilih melaporkan secara anonim ketika yang melakukan kesalahan memiliki reputasi yang tidak baik, akan tetapi lebih memilih untuk melaporkan menggunakan outlet non-anonim ketika pelaku memiliki reputasi yang baik.

Kaplan et al., (2009) meneliti dari efek kekuatan kemanan hotline terhadap pelaporan whistleblower. Mereka menemukan bahwa partisipan secara signifikan lebih kecil kemungkinannya untuk melaporkan kesalahan yang terjadi ketika kebijakan perlindungan whistleblower anonim yang kuat (misalnya, hotline itu dikelola oleh pihak ketiga atau eksternal, serta dipertahankan dalam lingkungan rahasia yang dikontrol dengan ketat). Penelitian ini memprediksi bahwa semakin tinggi tingkat keamanan hotline whistleblower , maka akan semakin tinggi kemungkinan whistleblower untuk melakukan pelaporan kesalahan. Hasil penelitian menyatakan bahwa whistleblower lebih cenderung untuk melaporkan melalui hotline secara internal dan tidak adanya kontrol informasi. Penelitian yang dilakukan Kaplan et al., (2009) menyatakan bahwa whistleblower enggan melakukan pelaporan kesalahan pada pihak ketiga. Deskripsi kebijakan pada hotline whistleblower mungkin telah cukup untuk menciptakan kepercayaan pada saluran pelaporan anonim. Oleh karena itu, proteksi yang rendah dalam kebijakan hotline whistleblower benar-benar dapat membahayakan orang yang melakukan pengungkapan kecurangan.

Salah satu cara yang dilakukan untuk mengurangi rasa takut terhadap pembalasan dan meningkatkan kasediaan karyawan untuk melaporkan, organisasi telah menyertakan jenis proteksi dalam kebijakan hotline whistleblower (Wainberg dan Perreault, 2006). Yang artinya, selain menyediakan saluran pelaporan, rahasia dan anonim, juga memasukkan bentuk-bentuk proteksi khusus dari pembalasan (seperti kehilangan pekerjaan, kehilangan promosi, pelecehan, konsekuensi keuangan, profesionalisme yang jatuh, dan hukuman). ACFE (2012) merekomendasikan proteksi terhadap pembalasan untukditawarkan kepada karyawan.

$\mathbf{H}_{3}$ : Proteksi berpengaruh positif terhadap keputusan pengungkapan kecurangan.

\section{METODE PENELITIAN}

Jenis penelitian yang digunakan dalam penelitian ini adalah penelitian kuantitatif. Desain eksperimen yang digunakan adalah eksperimental between-subject dengan $2 \times 2$ faktorial yang terdiri dari: 1) dukungan atasan, dan 2) proteksi. Eksperimen menggunakan sketsa kasus untuk memanipulasi variabel dukungan atasan dan proteksi secara konsisten (Mesmer-Magnus dan Viswesvaran, 2005; Miceli et al., 2008). Kemudian sketsa disajikan dalam fokus orang ketiga untuk meminimalkan self reporting bias dan subjek diukur dari kemungkinan bahwa fokus orang pertama dan orang ketiga yang akan melaporkan kecurangan. Populasi dalam penelitian ini adalah mahasiswa Magister Manajemen Universitas Negeri Padang dan S2 Akuntansi Universitas Andalas, Pengambilan sampel dalam penelitian ini menggunakan purposive sampling, mahasiswa magister manajemen/ UNP tahun 2018 sebanyak 25 mahasiswa dan 2019 sebanyak 25 mahasiswa dan mahasiswa Akuntansi/ UNAND tahun 2018 sebanyak 16 mahasiswa dan tahun 2019 sebanyak 15 mahasiswa maka total sampel yaitu 81 mahasiswa.

Jenis data adalah data subjek, yaitu penelitian berupa instruksi, sketsa kasus, dan kuesioner demografi. Instrumen penelitian pada penelitian ini dibagi menjadi dua bagian. Bagian pertama yaitu responden diminta untuk mengisi data demografis seperti nama, umur, jenis kelamin, etnik dan tempat pendidikan. Bagian kedua yaitu berisi sketsa kasus yang akan dijawab oleh responden berkaitan dengan variabel dependen yaitu keputusan pengungkapan kecurangan 
pada pemerintah daerah di Sumatera Barat serta variabel independen yaitu dukungan atasan (tinggi dan rendah) dan proteksi (tinggi dan rendah), kemudian pada akhir kasus responden diminta menjawab 2 pertanyaan untuk memastikan pemahaman responden terhadap kasus yang diberikan dengan skala 1-10. Instrumen penelitian ini mengacu pada instrumen eksperimen penelitian Priyastiwi (2017) dengan beberapa perubahan yang disesuaikan dengan kondisi penelitian ini.

\section{HASIL DAN PEMBAHASAN \\ Deskripsi Data Penelitian}

Penelitian ini menggunakan metode eksperimen factorial design $2 \times 2$ melalui penyebaran kuesioner sketsa kasus kepada mahasiswa. Mahasiswa yang dijadikan pertisipan dalam penelitian ini adalah mahasiswa Magister Manajemen Universitas Negeri Padang dan mahasiswa S2 Akuntansi Universitas Andalas yang telah bekerja, karena mahasiswa tersebut dianggap sudah memiliki pengetahuan tentang kecurangan yang terjadi di pemerintah daerah. Jumlah kuesioner yang disebarkan adalah sebanyak 81 kuesioner. Kuesioner disebarkan kepada partisipan yang terkumpul dalam beberapa kelas dalam hari yang berbeda. Kuesioner yang dikembalikan sebanyak 76 kuesioner. Setelah dilakukan manipulation check ada 18 kuesioner tidak lulus uji manipulasi sehingga jumlah kuesioner yang dapat diolah adalah 58 kuesioner. Berikut ini ringkasan dari data penyebaran hingga pengembalian kuesioner.

Tabel 1

Tingkat Pengembalian Kuesioner

\begin{tabular}{|c|c|c|}
\hline No & Keterangan & Jumlah \\
\hline 1 & Penyebaran kuesioner & 81 \\
\hline 2 & Kuesiner yang tidak dikembalikan & 5 \\
\hline 3 & Kuesioner yang dikembalikan & 76 \\
\hline 4 & Kuesioner yang tidak lulus uji manipulasi & 18 \\
\hline \multirow[t]{2}{*}{5} & Kuesioner yang diisi lengkap dan bisa diolah & 58 \\
\hline & Response rate & $71,6 \%$ \\
\hline
\end{tabular}

Sumber: Data penelitian yang diolah, 2020

Sebelum pengolahan data, peneliti melakukan pemeriksaan jawaban atas pertanyaan pada manipulation check. Berdasarkan data yang dikumpulkan dari 76 partisipan, data yang dapat diolah setelah lolos uji manipulation check hanya 56 orang. Partisipan yang lolos uji manipulation check adalah 18 orang. Jadi, dapat disimpulkan response rate penelitian adalah $71,6 \%$.

\section{Hasil}

Pengujian statistik yang dilakukan adalah uji hipotesis dengan menggunakan SPSS windows Release 21

\section{Uji Asumsi Klasik}

Uji asumsi klasik meliputi uji normalitas dan uji homogenitas. Pengujian Normalitas terhadap data menggunakan uji statistik Kolmogorov-Smirnov $(K S)$ dengan hasil nilai signifikan 0,125, hal ini berarti data berdistribusi normal karena nilai signifikan $>0,05$. Hasil pengujian homogenitas 
diperoleh signifikan $>0,05$ yaitu 0,131 , artinya variabel yang diteliti homogen. Hasil uji tersebut dapat dilihat bawah ini.

Tabel 2

Hasil Uji Asumsi Klasik

\begin{tabular}{cccc}
\hline \multicolumn{2}{c}{ Uji Normalitas } & \multicolumn{2}{c}{ Uji Homogenitas } \\
\hline $\mathrm{N}$ & 58 & $\mathrm{~N}$ & 58 \\
Kolmogorov- & 1,178 & Levene Statistic & 1,696 \\
Smirnov Z & & & \\
Asymp. Sig. & 0,125 & Asymp. Sig. & 0,131 \\
\hline
\end{tabular}

\section{Uji Hipotesis}

Uji hipotesis yang digunakan dalam penelitian ini yaitu uji statistik two way ANOVA (analysis of variance) yang bertujuan untuk mengetahui pengaruh variabel gender, dukungan atasan dan proteksi terhadap keputusan pengungkapan kecurangan pada pemerintah daerah di Sumatera Barat. Baik hipotesis pertama, kedua, maupun ketiga masing-masing menggunakan uji statistik two way ANOVA (analysis of variance). Hasil pengujian hipotesis terhadap hipotesis 1 tidak terpenuhi karena nilai signifikan $>0,05$ yaitu 0,730 . Hipotesis 2 terpenuhi karena nilai signifikan $<0,05$ yaitu 0,000 dan hipotesis 3 terpenuhi karena nilai signifikan $<0,05$ yaitu 0,0 . Berikut hasil dari uji hipotesis pada penelitian ini:

Tabel 3

Hasil uji Hipotesis

Tests of Between-Subjects Effects

\begin{tabular}{|c|c|c|c|c|c|}
\hline \multirow{2}{*}{$\begin{array}{c}\text { Dependent Variable: } \\
\text { Source }\end{array}$} & \multicolumn{5}{|c|}{$\begin{array}{c}\text { Keputusan Pengungkapan Kecurangan Pada Pemerintah Daerah } \\
\text { di Sumatera Barat }\end{array}$} \\
\hline & $\begin{array}{l}\text { Type III Sum of } \\
\text { Squares }\end{array}$ & $D f$ & Mean Square & $F$ & Sig. \\
\hline Corrected Model & $412,995^{\mathrm{a}}$ & 7 & 58,999 & 7,720 & ,000 \\
\hline Intercept & 7550,666 & 1 & 7550,666 & 988,027 &, 000 \\
\hline$x 1$ & ,919 & 1 & ,919 &, 120 &, 730 \\
\hline$x 2$ & 188,223 & 1 & 188,223 & 24,630 &, 000 \\
\hline$x 3$ & 119,610 & 1 & 119,610 & 15,651 &, 000 \\
\hline$x 1 * x 2$ & ,976 & 1 & ,976 &, 128 &, 722 \\
\hline$x 1 * x 3$ & 2,919 & 1 & 2,919 & ,382 &, 539 \\
\hline$x 2 * x 3$ & 16,709 & 1 & 16,709 & 2,186 &, 146 \\
\hline$x 1 * x 2 * x 3$ & 3,874 & 1 & 3,874 &, 507 & ,480 \\
\hline Error & 382,108 & 50 & 7,642 & & \\
\hline Total & 10084,000 & 58 & & & \\
\hline Corrected Total & 795,103 & 57 & & & \\
\hline a. $\mathrm{R}$ Squared $=, 519($ & Adjusted R Squar & $=, 452)$ & & & \\
\hline
\end{tabular}

Sumber: Data penelitian yang diolah, 2020 


\section{Pembahasan \\ Pengaruh Gender terhadap Keputusan Pengungkapan Kecurangan pada Pemerintah Daerah di Sumatera Barat}

Hipotesis pertama (H1) yang dirumuskan dalam penelitian ini adalah laki-laki lebih cenderung dalam melakukan tindakan keputusan pengungkapan kecurangan daripada perempuan. Berdasarkan hasil uji hipotesis dengan uji ANOVA dua arah (two way ANOVA), menunjukan bahwa variabel gender mendapatkan nilai signifikan 0,730 . Karena nilai signifikan $>a=0,05$ maka dapat diambil kesimpulan bahwa Gender tidak berpengaruh secara signifikan terhadap keputusan pengungkapan kecurangan pada pemerintah daerah di Sumatera Barat. Hal ini menunjukan bahwa baik laki-laki maupun perempuan sama-sama tidak melakukan pengungkapan kecurangan, sehingga hipotesis 1 tidak terpenuhi.

Hasil penelitian ini tidak sejalan dengan hasil penelitian Vermeir (2008) yang menyebutkan bahwa perempuan lebih etis dalam penilaian dan bersikap, karena perempuan lebih memikirkan konsekuensi yang akan diterima ketika menjadi whistleblower, seperti dikucilkan atau diberi sanksi lainnya. Sedangkan laki-laki dianggap lebih mampu dalam mengatasi masalah sendiri dan mampu menerima konsekuensi yang akan diterimanya ketika melakukan whistleblowing.

\section{Pengaruh Dukungan Atasan terhadap Keputusan Pengungkapan Kecurangan pada Pemerintah Daerah di Sumatera Barat}

Hipotesis kedua (H2) yang dirumuskan dalam penelitian ini adalah dukungan atasan berpengaruh positif terhadap keputusan pengungkapan kecurangan pada pemerintah daerah di Sumatera Barat. Berdasarkan hasil uji hipotesis dengan uji ANOVA dua arah (two way ANOVA), menunjukan bahwa variabel dukungan atasan mendapatkan nilai signifikan 0,000 . Karena nilai signifikan $<a$ $=0,05$ maka dapat diambil kesimpulan bahwa dukungan atasan berpengaruh secara signifikan terhadap keputusan pengungkapan kecurangan pada pemerintah daerah di Sumatera Barat. Dukungan atasan yang tinggi menghasilkan kemungkinan pengungkapan kecurangan yang lebih tinggi $(M=14,538)$ dibandingkan dengan dukungan atasan yang rendah $(M=10,573)$. Hal ini menunjukan bahwa proses keputusan pengungkapan kecurangan akan terjadi jika adanya interaksi yang baik antara pelapor dengan atasan. Karena proses pengungkapan kecurangan adalah perilaku prososial, sehingga jika pelapor ditanggapi dan dipercaya oleh atasan, maka pelapor akan lebih berani mengungkapakan kecurangan sehingga hipotesis 2 terpenuhi.

Berdasarkan hasil hipotesis 2 diterima maka sejalan dengan penelitian (Eisenberger et al., 2002) yang menyatakan bahwa karyawan memandang atasan berkontribusi terhadap kesejahteraan mereka, karena atasan bertindak sebagai agen organisasi yang memiliki tanggung jawab untuk memimpin dan mengevaluasi kinerja bawahannya. Pandangan karyawan terhadap atasannya yaitu atasan bertindak menguntungkan karyawan sebagai indikasi dari dukungan organisasi. Penelitian ini diperkuat dengan hasil penelitian Eisenberger et al., (2010) yang menyatakan bahwa karyawan membentuk persepsi tentang kesamaan antara atasan dengan organisasi sebagai perwujudan dari organisasi pengawas (SOE/ Supervisor Organization Embodiment). Jika semakin besar SOE, maka semakin besar karyawan merasakan bahwa perlakuan yang diberikan atasan adalah sebagai perlakuan dari organisasi pula. Hasil penelitian lainnya yang sejalan dengan hasil penelitian ini adalah penelitian Near dan Miceli (1996), penelitian tersebut menyebutkan bahwa kurangnya dukungan dari atasan dan top manajemen 
akan menurunkan whistleblowing. Pemimpin yang memiliki etika etis akan mendukung, dan memotivasi karyawan untuk mengungkap kesalahan yang terjadi.

\section{Pengaruh Proteksi terhadap keputusan pengungkapan kecurangan pada pemerintah daerah di Sumatera Barat}

Hipotesis ketiga (H3) yang dirumuskan dalam penelitian ini adalah proteksi berpengaruh positif terhadap keputusan pengungkapan kecurangan. Berdasarkan hasil uji hipotesis dengan uji ANOVA dua arah (two way ANOVA), menunjukan bahwa variabel proteksi mendapatkan nilai signifikan 0,000. Karena nilai signifikan $<\mathrm{a}=0,05$ maka dapat diambil kesimpulan bahwa proteksi berpengaruh secara signifikan terhadap keputusan pengungkapan kecurangan pada pemerintah daerah di Sumatera Barat. Proteksi yang tinggi menghasilkan kemungkinan keputusan pengungkapan kecurangan yang lebih tinggi $(\mathrm{M}=14,135)$ dibandingkan dengan proteksi yang rendah $(\mathrm{M}=10,975)$. Hal ini didasarkan atas teori pertukaran sosial, karena pelapor tidak mengharapkan imbalan dari organisasi, akan tetapi karena ingin membantu organisasi. Pelapor mengharapkan bahwa mereka dapat terbebas dari perilaku pembalasan yang terbukti dari pemberian perlindungan yang tinggi, maka mereka akan lebih berani melakukan pengungkapan kecurangan yang ada pada organisasi sehingga hipotesis 3 terpenuhi.

Berdasarkan hasil hipotesis 3 diterima yang sejalan dengan penelitian Curtis dan Taylor (2009) telah melakukan survey terhadap auditor dan menemukan bahwa partisipan kurang bersedia untuk melakukan pelaporan kesalahan yang tidak etis tersebut ketika identitas mereka diungkapkan. Penelitian ini diperkuat dengan hasil penelitian Robertson et al., (2011) menyatakan bahwa auditor lebih memilih melaporkan secara anonim ketika yang melakukan kesalahan memiliki reputasi yang tidak baik, akan tetapi lebih memilih untuk melaporkan menggunakan outlet non-anonim ketika pelaku memiliki reputasi yang baik.

Hasil penelitian lainnya yang sejalan dengan hasil penelitian ini adalah Kaplan et al., (2009), hasil penelitian tersebut menyebutkan bahwa dari efek kekuatan keamanan hotline terhadap pelaporan whistleblower. Mereka menemukan bahwa partisipan secara signifikan lebih kecil kemungkinannya untuk melaporkan kesalahan yang terjadi ketika kebijakan perlindungan whistleblower anonim yang kuat (misalnya, hotline itu dikelola oleh pihak ketiga atau eksternal, serta dipertahankan dalam lingkungan rahasia yang dikontrol dengan ketat). Penelitian ini memprediksi bahwa semakin tinggi tingkat keamanan hotline whistleblower , maka akan semakin tinggi kemungkinan whistleblower untuk melakukan pelaporan kesalahan. Hasil penelitian menyatakan bahwa whistleblower lebih cenderung untuk melaporkan melalui hotline secara internal dan tidak adanya kontrol informasi. Penelitian yang dilakukan Kaplan et al., (2009) menyatakan bahwa whistleblower enggan melakukan pelaporan kesalahan pada pihak ketiga. Deskripsi kebijakan pada hotline whistleblower mungkin telah cukup untuk menciptakan kepercayaan pada saluran pelaporan anonim. Oleh karena itu, proteksi yang rendah dalam kebijakan hotline whistleblower benar-benar dapat membahayakan orang yang melakukan pengungkapan kecurangan.

Salah satu cara yang dilakukan untuk mengurangi rasa takut terhadap pembalasan dan meningkatkan kasediaan karyawan untuk melaporkan, organisasi telah menyertakan jenis proteksi dalam kebijakan hotline whistleblower (Wainberg dan Perreault, 2006). Yang artinya, selain menyediakan saluran pelaporan, rahasia dan anonim, juga memasukkan bentuk-bentuk proteksi khusus dari pembalasan (seperti kehilangan pekerjaan, kehilangan promosi, pelecehan, konsekuensi keuangan, profesionalisme yang jatuh, dan hukuman). 


\section{SIMPULAN, KETERBATASAN DAN SARAN \\ Simpulan}

Berdasarkan hasil penelitian dan pengujian hipotesis yang telah dilakukan diatas maka dapat diambil kesimpulan 1) Antara laki-laki dan perempuan sama-sama tidak melakukan tindakan pengungkapan kecurangan jika dilihat dari nilai signifikan 0,730 . Karena nilai signifikan $>a=$ 0,05 maka dapat diambil kesimpulan bahwa Gender tidak berpengaruh secara signifikan terhadap keputusan pengungkapan kecurangan pada pemerintah daerah di Sumatera Barat. 2) Pelapor yang mendapat dukungan atasan tinggi akan cenderung melakukan keputusan pengungkapan kecurangan pada pemerintah daerah di Sumatera Barat dibandingkan dengan pelapor yang mendapat dukungan atasan rendah jika dilihat dari nilai signifikan sebesar $0,000<0,05$. 3) Pelapor yang mendapat proteksi tinggi akan lebih cenderung melakukan keputusan pengungkapan kecurangan pada pemerintah daerah di Sumatera Barat dibandingkan dengan pelapor yang mendapat proteksi rendah jika dilihat dari nilai signifikan $0,000<0,05$.

\section{Keterbatasan}

Dalam penelitian yang dilakukan penulis tidak terlepas dari adanya keterbatasan. Adapun beberapa keterbatasan yang ditemui. Pertama, penelitian ini hanya berfokuskan pada faktor individual yaitu gender. Penelitian ini juga hanya menggunakan dua faktor organisasional yaitu dukungan atasan dan proteksi. Kedua, variabel gender tidak berpengaruh secara signifikan terhadap keputusan pengungkapan kecurangan pada pemerintah daerah di Sumatera Barat. Hal ini mungkin disebabkan karena terbatasnya partisipan pada penelitian ini. Ketiga, responden dalam penelitian ini sebagian kecil kurang memahami prosedur penelitian yang dijelaskan melalui manipulasi yang diberikan, sehingga sebagian kecil tidak lolos uji manipulasi.

\section{Saran}

Penelitian selanjutnya dapat menggunakan variabel faktor individual lain yang diukur dalam penelitian ini seperti agama, orientasi filosofi, pekerjaan, kepuasan kerja, pengalaman kerja, komitmen organisasional, dan faktor kepribadian. Sementara faktor organisasional yang banyak diuji adalah kode etik, jenis industri, iklim/budaya organisasi, imbalan dan pinalti, pelatihan dan lingkungan budaya eksternal. Peneliti berikutnya disarankan untuk memilih tempat penelitian yang berbeda dan memperluas objek penelitian agar didapatkan hasil penelitian yang akurat dan dapat memberikan penjelasan mengenai perlakuan yang diberikan kepada partisipan eksperimen secara lebih baik sehingga responden dapat memehami penelitian dengan baik dan lolos uji manipulasi.

\section{DAFTAR PUSTAKA}

Aselage,J., \& Eisenberger,R. (2003). Perceived organizational support and psychologicalcontracts: Atheoretical integration. Journal of organizational Behavior, 24, 491-509.

Alleyne, Philmore, Mohammad Hudaib, dan Richard Pike. (2012). Towards a conceptual model of whistle-blowing intentions among external auditors. Scient Direct Journal.

Assosiation of Certified Fraud Examiners (ACFE).(2012). Report to the Nations on Occupational Fraud and Abuse. Austin, TX: ACFE.

Bagustianto, Rizki, dan Nurkholis. 2016. "Faktor-Faktor Yang Mempengaruhi Minat Pegawai Negeri Sipil (PNS) Untuk Melakukan Tindakan Whistleblowing (Studi Pada PNS BPK RI)". Jurnal Ekonomi dan Keuangan Volume 19, Nomor 2, Juni 2015: 276-295. 
Bouville, Mathieu. (2007). "Whistle-Blowing and Morality". Journal of Business Ethics. 2008 (81), 579-585.

Brehm, J. W. (1966). A Theory of Psychology Reactance. New York, NY: Academic Press.

Brehm, dan S. S. Brehm. (1981). Psychologycal Reactance: A Theory of Freedom and Control. New York, NY: Academic Press.

Coate, dan Frey. 2000. Some evidence on the ethical disposition of accounting students: context and gender implications. TeachingBusiness Ehis. Volume 4, Nomor 5, 2000. 379-404.

Curtis, M., dan E. Taylor. (2009). Whistleblowing in public accounting: influence of identify disclosure, situational context, and personal characteristics. Accounting and the public interest, Volume 9, Nomor 1, 2009, 191-220.

Davis, S., F. T. DeZoort, and L. S. Kopp. (2006). The effect of obedience pressure and perceived responsibility on management accountants' creation of budgetary slack. Behavioral Research in Accounting, Volume 18, 2006, 19-35.

DeZoort, F. T., and A. T. Lord. (1997). A review and synthesis of pressure effects research in accounting. Journal of Accounting Literature, Volume 16, 1997, 28-85.

Elias, Rafik. 2008. "Auditing student's professional commitment and anticipatory socialization an their relationship to whistleblowing". Managerial auditing journal, Vol.3 No.3, pp 283-294.

Eisenberger, R.; Huntington, R.; Hutchison, S.; dan Sowa, D. (1986). Perceived organizational support. Journal of Applied Pshchology, volume 71, Nomor 3, 1986, 500-507.

Eisenberger, R.; Stinglhamber, F; Vandenberghe, C.; Sucharski, I.L; dan Rhoades, L. (2002). Perceived suppervisor support: Conribution to perceveid organizational support and employee retention. Journal of Applied Psychology, Volume I87, Nomor 3, 2002, 565-571.

Eisenberger, R., Karagonlar, G., Stinglhamber, F., Neves, P., Beeker, T. E., Gonzalez-Morales, M. G., and Steiger-Mueller, M. (2010). Leader-member exchange and affective organizational commitment: the contribution of supervisor's organizational embodiment. Journal of Applied Psychology. Volume 16, 2010, 1-20.

Ghozali, Imam. 2007. Aplikasi Analisis Multivariate dengan program SPSS. Semarang: Badan Penerbit Universitas Diponegoro.

Hanif, Rheny Afriana, dan Fajar Odiatma. 2017. "Pengaruh Personal Cost Reporting, Status Wrong Doer dan Tingkat Keseriusan Kesalahan Terhadap Whistleblowing Intention”. Jurnal Akuntansi Keuangan dan Bisnis Vol. 10, No. 1, Mei 2017, 11-20.

Hoffman, W. Michael and Robert E. (2008).“A Business Ethics Theory of Whistleblowing".Journal of Business and Environmental Ethics.BentleyUniversiy.

Waltham MA. USA, 45-59.

https://acch.kpk.go.id/id/berkas/penindakan/penyidikan/penyidikan-2016, diakses tanggal 15 Oktober 2018.

http://www.beritasatu.com/hukum/347873-icw-sebut-pelaku-korupsi-terbanyak-dari-pejabatpemda.html, diakses tanggal 15 Oktober 2018.

Kaplan, Steven. E, dan Joseph J. Schultz. 2007. "Intentions to Report Questionable Acts: An Examination of the Influence of Anonymous Reporting Channel, Internal Audit Quality, and Setting". Journal of Business Ethics (2007) 71:109-124.

Keil, M., Tiwana, A., Sainsbury, R. Dan Sneha, S. (2010). Thoward a theory of whistleblowing intentions: a benefit-to-cost differential perspective. Decision Sciences volume 41, nomor $4,2010,787-812$. 
Komite Nasional Kebijakan Governance. 2008. Pedoman Sistem Pelaporan Pelanggaran-SPP (Whistleblowing System-WBS).

Kottke, J. L., dan Sharafinski, C. E. (1988). Measuring perceived supervisory and organizational support. Educational and Psychological Measurement, volume 48, 1075-1079.

Lewis, 2005. Whistleblowing dipandang sebagai bagian dari strategi untuk menjaga dan meningkatkan kualitas.

Malik, 2010. Indeks persepsi korupsi 2007 transparency internasional

Mermer-Magnus, J. R., dan Viswesvaran, C. (2005) whistleblowing in organizations: an examination of correlates of whistleblowing intentions, actions, and reliation. Journal of Business Ethics, Volume 62, nomor 3, 2005, 277-297.

Miceli, M. P. (2004). Whistle-blowing research and the insider: lessons and yet o be learned. Journal of management inquiry., Volume 13, Nomor 4, 2004, 364-366.

Near, J. P., and Miceli, M. P. (1996). Whistle-blowing myth and reality. Journal of Management Inquiry, Volume 22, Nomor 3, 1996, 507-526.

Priyastiwi, dan Abdul Halim. (2017). Pengaruh dukungan atasan dan proteksi terhadap keputusan pengungkapan kecurangan pada pemerintah daerah di Indonesia, SNA XX Jember.

Rhoades,L.,\&Eisenberger,R.(2002).Perceivedorganizationalsupport:areviewoftheliterature.Journ alofAppliedPsychology, 87(4),698-714.

Riduwan, 2003. Dasar-dasar Statistika, cetakan ketiga, Bandung: Afabeta.

Robertson, J. C., c. M. Stefaniak, and M. B. Curtis (2011). Does wrongdoer reputation matter? Impact of auditor wrongdoerbperformance and likeability reputations on fellow auditor's intention to take action and choice of reporting outlet. Behavioral Research in Accounting, Volume 23, Nomor 2, 2011, 207-234.

Rouseau, D. M. (1989). Psycological and implied contracts in organizations. Employee Responsibilities and Rights Journal. Volume 2, 1989, 121-139.

Rothschild, Joyce, dan Terance D. Miethe. 1999. "Whistle-Blower Disclosures and Management Retaliation". Work and Occupations. Vol. 26; 107-128.

Seifert, D.L,J. T. Sweeney, J. A. Joireman, and J. M. Thotnton. 2010. The influence of organizational justice on accountant whistleblowing. Accounting, organizational and sociaty $35,707-717$.

Sekaran, Uma. 2014. Research Methods For Business (Edisi 4). Jakarta: Salemba Empat.

Setiawati, Luh Putu, Maria M. Ratna Sari. 2016. "Profesionalisme, Komitmen Organisasi, Intensitas Moral dan Tindakan Akuntan Melakukan Whistleblowing”. E-Jurnal Akuntansi Universitas Udayana Vol.17.1. Oktober (2016): 257-282.

Setyawati, Intan, dkk. 2015. "Faktor-faktor yang mempengaruhi niat untuk melakukan whistleblowing internal". Jurnal Ekonomi Bisnis Volume 17 Nomor 02.

Slamet, S. Sarwono, dan Amiluhur Soeroso. 2001. Determinasi demografi terhadap perilaku karitatif keorganisasian. Jurnal Siasat Bisnis, Volume 1, Nomor 6.

Sugiyono. 2014. Metode Penelitian Kuantitatif, Kualitatif dan R\&D. Cetakan ke-21 Desember 2014. Bandung: CV Alfabeta.

Surat Edaran Mahkamah Agung (SEMA) RI Nomor 4 Tahun 2011 Tentang Perlakuan Bagi Pelapor Tindak Pidana (Whistleblower) dan saksi pelaku (justice collaborators) di dalam Perkara Tindak Pidana Tertentu.

Undang-Undang Nomor 13 Tahun 2006 tentang Perlindungan Saksi dan Korban.

Undang-Undang Nomor 31 Tahun 1999 tentang Tindak Pidana Korupsi. 
Vermeir, I and Van Kenhove,P. 2008."Gender Different in Double Standar".Journal Business Ethic, 8(2),281-295.

Wainberg, J., and Perreault, S. (2006). Whistleblowing in audit firms: do explisit pretections from retaliation activate implicit threats of reprisal. Behavioral in Accounting, Volume 28, Nomor 1, 2006, 83-93.

Winardi, Rijadh Djatu. 2013. "The Influence of Individual and Situational Factors on Lowerlevel Civil Servants' Whistle-blowing Intention in Indonesia". Journal of Indonesian Economy and Business Volume 28, Number 3, 2013, 361-376. 